Volume 10 No. 2 September 2019

P-ISSN 2086-6178 E-ISSN 2579-3292

http://ejournal.bsi.ac.id/ejurnal/index.php/jkom

\title{
Pengaruh Tulisan Ernest Prakasa Mengenai Dr Zakir Naik Di Twitter Terhadap Citra Ernest Prakasa Di Desa Bojonggede
}

\author{
Rio Septian \\ Universitas Bina Sarana Informatika \\ rio.rse@bsi.ac.id
}

Cara Sitasi: Septian Rio. Pengaruh Tulisan Ernest Perkasa Mengenai Dr Zakir Naik Di Twitter Terhadap Citra Ernest Prakasa Di Desa Bojonggede. Jurnal Komunikasi 10(2), 176-183.

\begin{abstract}
The aim of this study was to find out the effect of ernest prakasa's Posts about Zakir Naik in Twitter toward his negative image in Bojonggede. The approach of this study was quantitative descriptive. To collect the data, the researcher used questionnaire adn in analyzing the data, the researcher used Parametric statistics of regression and correlation test. This research was conducted in Bojonggede and took 100 respondents as the sample of the study. After the evaluation has been conducted, it was found that there is a significant relationship between Ernest Prakasa's posts about DR Zakir Naik on twitter with his negative image in Bojonggede. The details is ; 71.7\% claim that the negative image of Ernest Prakasa in Bojonggede because of his posts about Zakir Naik, and $28,3 \%$ of other factors.
\end{abstract}

Keywords : Twitter, Ernest Prakasa, Zakir Naik

\section{PENDAHULUAN}

Keterbukaan informasi yang ditawarkan internet sangat dimanfaatkan masyarakat untuk kehidupan sehari-hari. Berbagai macam media sosial bermunculan setelah era internet populer di penjuru dunia. Kini media sosial seperti Facebook, Instagram, Twitter, dll sudah sangat akrab dengan masyarakat dunia.

Pada tanggal 01 Maret 2017 Indonesia kedatangan ulama terkenal asal India, DR. Zakir Naik. Pada hari sabtu tanggal 04 Maret 2017, Zakir Naik bertemu dengan Wakil Presiden Jusuf Kalla di rumah Dinas Wapres di J1 Diponegoro, Jakarta Pusat. Pertemuan ini dipublikasikan di akun Facebook Hanny Kristianto, salah seorang panitia Persiapan Zakir Naik Visit Indonesia 2017.

Pada hari minggu 05 Maret 2017 Ernest menjadi pusat perhatian setelah melontarkan tulisan yang bernada tuduhan kepada Zakir Naik di media sosial Twitter. Dengan berbekal penelusuran media asal Inggris, Daily Mail, yang bertajuk Islamic preacher Zakir Naik 'gave Rs 80,000 to ISIS recruit'. Artikel tersebut melacak aliran dana dari Zakir Naik ke Abu Anas, seorang anggota ISIS di Suriah yang terkait dengan teror bom Dhaka pada bulan Juli 2016. Kemudian Ernest ingin menunjukkan bahwa ada korelasi antara kegiatan Zakir Naik dengan aktivitas ISIS (Islamic State of Iraq and Syria).
Berikut adalah tulisan Ernset Prakasa di akun twitternya : "JK dgn hangat menjamu Zakir Naik, org yg terang2an mendanai ISIS. Sulit dipahami,"

Tak lama setelah tulisan itu, respon dari publik mengecam keras tuduhan Ernest. Masyarakat pengguna internet (netizen), khususnya umat Islam menyebut Ernest telah melakukan pelecehan terhadap tokoh dan ulama Islam. Dunia media sosial Twitter langsung diramaikan oleh netizen yang menyerukan kecaman pemboikotan terhadap Ernest dan juga terhadap merek produk jamu yang diiklankan oleh Ernest. Tanda pagar (tagar) \#BoikotTolakAngin dan \#BoikotErnest pun menjadi tema yang paling tren dibicarakan di ranah Twitter (trending topic).

Imbas dari kicauan tersebut, PT Sido Muncul tak lagi memperpanjang kontrak Ernest sebagai brand ambassador produk Tolak Angin. Akibat dari kejadian tersebut pula, Ernest gagal tampil di acara Comic Life bersama sejumlah komika lainnya seperti Yudha Keling, Arafah, serta Mongol, di AAC Dayan Dawood Darussalam, Banda Aceh pada hari Sabtu 11 Maret 2017. Warga Aceh geram dan menolak kehadiran Ernest pada acara tersebut. Panitia acara tersebut memberi keterangan resmi di laman facebook.

Tidak hanya itu saja, netizen juga menyerukan tidak akan menonton film hasil karya Ernest Prakasa atau 
program, televisi yang dibintangi Ernest. Karena kasus tersebut pula, Ernest mendapat ancaman dari berbagai pihak. Tidak hanya kepada Ernest, keluargapun ikut jadi sasaran ancaman. Bahkan Ernest sudah mendapat ancaman fisik dari tetangganya.

Kemudian Ernest segera menyampaikan permintaan maaf atas tuduhannya terhadap Zakir Naik. Ernest mengakui kesalahannya karena terlalu percaya dengan artikel yang ada di Daily Mail tersebut. Namun meski sudah melakukan permintaan maaf, kecaman terhadap Ernest terus mengalir.

Mengapa tulisan yang dianggap menghina itu menimbulkan masalah di masyarakat? Ini dikarenakan yang menyampaikan pernyataan adalah seorang publik figur yang sudah tentu memiliki otoritas. Selain itu, alasan lain adalah karena Ernest yang berlatar belakang beragama Kristen dan merupakan keturunan Tionghoa, karena pada saat itu Indonesia memang sedang diramaikan oleh kasuskasus yang berhubungan dengan isu-isu SARA.

Berdasarkan uraian latar belakang masalah di atas, maka dapat dikemukakan suatu perumusan masalah sebagai berikut "Seberapa besar pengaruh tulisan Ernest Prakasa mengenai DR Zakir Naik sebagai pendana organisasi ISIS di Twitter terhadap citra Ernest Prakasa di Desa Bojonggede".

\section{METODOLOGI PENELITIAN Komunikasi}

Setiap orang memerlukan komunikasi dengan orang lain untuk mencapai suatu tujuan tertentu. Dalam berkomunikasi antara satu dengan yang lainnya, proses komunikasi tersebut menggunakan kata-kata, bahasa, simbol - simbol, gambar dan sebagainya agar orang yang diajak komunikasi (Komunikan) dapat mengerti pesan apa yang disampaikan oleh si penyampai pesan (komunikator).

(Mulyana, 2007) komunikasi adalah transmisi informasi, gagasan, emosi, keterampilan dan sebagainya, dengan menggunakan simbol-simbol, kata-kata, gambar, figur, grafik, dan sebagainya. Tindakan atau proses transmisi itulah yang biasanya disebut komunikasi.

(Mulyana, 2007) komunikasi adalah proses yang memungkinkan seseorang (komunikator) menyampaikan rangsangan (biasanya lambanglambang verbal) untuk mengubah perilaku orang lain (comunicate).

(Mulyana, 2007) komunikasi adalah proses dimana suatu ide dialihkan dari sumber kepada suatu penerima atau lebih, dengan maksud untuk mengubah tingkah laku mereka.
Dari beberapa defenisi diatas secara umum dapat disimpulkan bahwa komunikasi merupakan proses pengiriman atau pertukaran pesan (stimulus, signal, simbol atau informasi) baik dalam bentuk verbal maupun non-verbal dari pengirim kepada komunikan) dengan tujuan adanya perubahan, baik dalam aspek kognitif, afektif maupun psikomotorik dan behavioral.

(Mulyana, 2007) kebutuhan penyandi (encoder) dan penyandi balik (decoder) dalam proses komunikasi. Enkoder bertanggung jawab mengekspresikan maksud sumber dalam bentuk pesan. Dalam situasi tatap muka, kelompok kecil dan komunikasi publik (pidato), saluran komunikasinya adalah udara yang menyalurkan gelombang suara. Dalam komunikasi massa, terdapat banyak saluran : televisi, radio, surat kabar, buku, dan majalah.

Model Berlo juga melukiskan beberapa faktor pribadi yang mempengaruhi proses komunikasi : proses keterampilan berkomunikasi, pengetahuan system sosial dan lingkungan budaya sumber dan penerima. Menurut model Berlo, sumber dan penerima pesan dipengaruhi oleh faktor-faktor: keterampilan komunikasi, sikap, pengetahuan, system sosial, dan budaya. Pesan dikembangkan berdasarkan elemen, struktur, isi, perlakuan, dan kode. Salah satu kelebihan model Berlo adalah bahwa model ini tidak terbatas pada komunikasi public atau komunikasi massa namun juga komunikasi antar pribadi dan berbagai bentuk komunikasi tertulis.

\section{Media Baru (New Media)}

Perkembangan teknologi komunikasi yang terus mengalami inovasi memunculkan adanya komunikasi menggunakan media, misalnya internet. Internet adalah media baru yang digunakan masyarakat untuk berkomunikasi lebih sering daripada komunikasi tatap muka pada era digital. Internet atau interconnection-networking secara umum adalah sistem global dari seluruh jaringan computer yang saling terhubung dengan menggunakan standar Internet Protocol Suite yang disingkat dengan TCP/IP yang berguna untuk melayani seluruh pengguna di seluruh dunia. Internet pertama kali dikembangkan pada tahun 1969 oleh Departemen Pertahanan Amerika Serikat yang bermula dari sebuah proyek yang disebut ARPANET (Advanced Research Project Agency Network).

(McQuail, 2011) media baru adalah tempat dimana seluruh pesan komunikasi terdesentralisasi, distribusi pesan melalui satellite meningkatkan penggunaan jaringan kabel dari komputer, keterlibatan audiens dalam proses komunikasi yang meningkat. 
(Junaedi, 2013) menguraikan tiga ciri utama yang menandai kehadiran teknologi komunikasi baru atau media baru, yaitu :

\section{a. Interactivity}

Media baru memiliki sifat interaktif yang tingkatannya mendekati pada komunikasi antarpribadi secara tatap muka. Media komunikasi yang interaktif ini memungkinkan partisipasinya dapat berkomunikasi secara lebih akurat, lebih efektif dan lebih memuaskan.

b. Demassification

Demassification atau tidak bersifat massal, maksudnya adalah suatu pesan khusus dapat dipertukarkan secara individual diantara para partisipan yang terlibat dalam jumlah yang besar.

c. Asynchronous

Karakteristik ini bermakna bahwa teknologi komunikasi baru atau media baru mempunyai kemampuan untuk mengirimkan dan menerima pesan pada waktu-waktu yang dikehendaki oleh setiap individu peserta.

\section{Media Sosial (Social Media)}

Andreas Kaplan dan Michael Haenlein mendefinisikan media sosial sebagai sebuah kelompok aplikasi berbasis internet yang dibangun di atas dasar ideologi dan teknologi Web 2.0 dan memungkinkan penciptaan dan pertukaran usergenerated content. Web 2.0 menjadi platform dasar media sosial. Media sosial ada dalam berbagai bentuk yang berbeda, termasuk social network, forum internet, weblogs, social blogs, micro blogging, wiki, podcasts, gambar, video, rating, dan bookmark sosial. (Lesmana, 2012)

(Puntoadi, 2011) Definisi lain, media sosial adalah fitur berbasis website yang dapat membentuk jaringan serta memungkinkan orang untuk berinteraksi dalam sebuah komunitas. Pada sosial media kita dapat melakukan berbagai bentuk pertukaran, kolaborasi dan saling berkenalan dalam bentuk tulisan visual maupun audiovisual. Contohnya seperti Twitter, Facebook, Blog, Foursquare, dan lainnya.

(Purnama, 2011) media sosial mempunyai beberapa karakteristik khusus, diantaranya:

a. Jangkauan (reach): daya jangkauan media sosial dari skala kecil hingga khalayak global.

b. Aksesibilitas (accesibility): media sosial lebih mudah diakses oleh publik dengan biaya yang terjangkau.

c. Penggunaan (usability): media sosial relatif mudah digunakan karena tidak memerlukan keterampilan dan pelatihan khusus.

d. Aktualitas (immediacy): media sosial dapat memancing respon khalayak lebih cepat.

e. Tetap (permanence): media sosial dapat menggantikan komentar secara instan atau mudah melakukan proses pengeditan.

\section{Twitter}

(Dixon, 2012) Menyatakan bahwa Twitter is a microblogging messaging service that limit you up to 140 characters per message, including spaces and punctuation, to you update content.

Pada dasarnya Twitter merupakan layanan pesan instan yang memungkinkan penggunanya mengirim postingan kapan saja dan dari mana saja asalkan bisa online dengan gadget-nya.

(Dixon, 2012) fitur yang terdapat dalam Twitter sebagai berikut :

a. Followers dan Following

Followers (pengikut) merupakan akun atau orang lain yang mengikuti akun orang lain, sedangkan following (mengikuti) merupakan akun atau orang lain yang diikuti akun orang lain. Cara lain menggunakan twitter adalah untuk berbagi informasi dengan pengikut akun sendiri. Penggunaan twitter yang mengikuti akun itu akan menerima update dari akun tersebut, yang diposting di halaman utama mereka di twitter.

\section{b. Direct Message}

Twitter juga memungkin untuk mengirim pesan pribadi kepengguna yang mengikuti akun tersebut. Ini pada dasarnya adalah program $e$-mail yang diterapkan ke twitter. Jika pengguna twitter tidak mengikuti akun tersebut, mereka tetap dapat saling mengirim pesan lewat pesan pribadi.

\section{c. Twitter Search}

Salah satu fitur yang paling kuat dari twitter adalah memberi kemudahan pengguna untuk mencari untuk orang-orang tertentu, kata kunci, subjek, dan tempat - tempat.

d. Trending Topics

Salah satu bagian yang paling menarik dari twitter adalah trending topics. Trending topics ini adalah terdiri dari sepuluh topik yang sering disebut atau dibicarakan di twitter pada waktu tertentu. Trending topic akan berkisar dari berita, olahraga, dan barang-barang hiburan yang menghibur. Untuk update-an terbaru dari twitter jumlah 
trending topic menjadi dua puluh topik. Para perusahaan biasanya melakukan kegiatan promosi periklanan dengan menggunakan info dari trending topics tersebut memberi kesan bahwa perusahaan mereka up to date terhadap isu-isu yang sedang menjadi trend di twitter.

e.

Latest News

Twitter memungkinkan penggunanya dengan cepat mengejar ketinggalan berita terbaru. Begitu seseorang tahu tentang berita terbaru, dia dapat memposting informasi tersebut di twitter, dan dalam beberapa detik konten yang dibagi muncul di internet. (Dixon, 2012)

\section{f. Tweet}

Tulisan yang dapat di posting di timeline Twitter. Jumlahnya tidak melebihi 140 karakter dan biasanya dapat berisi informasi, obrolan, ungkapan hati atau katakata motivasi. Meskipun secara default tweet tersebut dibatasi hanya 140 karakter, sebenarnya para pengguna Twitter tetap bisa menulis tweet dengan panjang lebih dari itu atau bahkan tanpa batas. Anda bisa melakukan hal tersebut dengan memanfaatkan beberapa aplikasi seperti Twitlonger, Socialscape, dan lain-lain.

\section{Citra}

(Ardianto Elvinaro dan Soemirat, 2007) citra adalah pengetahuan mengenai kita dan sikap-sikap terhadap kita yang mempunyai kelompok-kelompok yang berbeda. Pengertian citra ini kemudian disitir oleh (Ardianto Elvinaro dan Soemirat, 2007) bahwa citra adalah dunia sekeliling kita yang memandang kita.

Citra bisa diketahui, diukur dan diubah. Penelitian mengenai citra organisasi (corporate image) telah membuktikan bahwa citra bisa diukur dan diubah, walaupun perubahan citra relatif lambat. Selanjutnya Ardianto dan Soemirat menjelaskan bagaimana efek kognitif dari komunikasi sangat mempengaruhi proses pembentukan citra seseorang. Proses pembentukan citra merupakan kesan yang diperoleh seseorang berdasarkan pengetahuan dan pengertiannya tentang fakta-fakta atau kenyataan.

(Ardianto Elvinaro dan Soemirat, 2007) mengungkapkan bahwa proses pembentukan citra dalam struktur kognitif yang sesuai dengan pengertian sistem komunikasi dijelaskan oleh John. S. Nimpoerno seperti yang dikutip Danasaputra ada empat komponen, yakni persepsi, kognisi, motivasi, dan sikap diartikan sebagai citra individu terhadap rangsang, oleh Walter Lipman disebut juga sebagai "Picture Our Head".

\section{a. Persepsi}

Diartikan sebagai hasil pengamatan terhadap suatu hal. Publik akan memberikan makna atau arti terhadap rangsang berdasarkan pengalamannya tersebut, kemampuan mempersepsi itulah yang dapat melanjutkan proses pembentukan citra. Persepsi akan positif bila informasi yang diberikan dapat memenuhi kognisi individu. Menurut (Rakhmat, 2009) persepsi adalah pengalaman tentang obyek, peristiwa, atau hubungan-hubungan yang diperoleh dengan menyimpulkan informasi dan menafsirkan pesan. Faktor-Faktor yang berperan dalam persepsi Menurut (Bimo Walgito, 2010) faktor-faktor yang berperan dalam persepsi:

b. Kognisi

(Bimo Walgito, 2010) kognisi berarti kemampuan jiwa manusia yang berhubungan dengan pengenalan. Jadi manusia harus mengenal stimulus atau rangsang yang diberikan agar memperoleh respon. Proses kognitif menggabungkan antara informasi yang diterima melalui indera tubuh manusia dengan informasi yang telah disimpan di ingatan jangka panjang. Kedua informasi tersebut diolah di ingatan kerja yang berfungsi sebagai tempat pemrosesan informasi.

c. Motivasi

Sebelum melangkah pada motivasi, perlu dipahami mengenai motiv terlebih dahulu. Menurut Branca (Bimo Walgito, 2010) motivasi adalah kekuatan yang tedapat dalam diri organisme yang mendorong untuk berbuat dan merupakan driving force. Hal-hal yang dapat mempengaruhi motiv disebut motivasi. Motivasi merupakan keadaan dalam diri individu atau organisme yang mendorong perilaku ke arah tujuan. (Bimo Walgito, 2010).

Dari pengertian motivasi di atas dapat dikemukakan bahwa motivasi mempunyai tiga aspek, pertama, kesiapan bergerak karena kebutuhan misalnya kebutuhan jasmani, karena keadaan lingkungan atau karena keadaan mental seperti bepikir dan ingatan. Kedua, perilaku yang timbul dan terarah karena keadaan. Ketiga, tujuan yang dituju oleh perilaku tersebut.

d. Sikap

Kecenderungan bertindak, persepsi, berpikir, dan merasa dalam objek, ide, situasi, atau nilai. Sikap bukan perilaku, tetapi merupakan kecenderungan untuk berperilaku dengan cara tertentu. Sikap mempunyai daya pendorong atau motivasi. Sikap juga mengandung aspek evaluatif, yakni mengandung nilai menyenangkan atau tidak, dan sikap yang 
dapat dipertahankan atau diubah. Komponen utama pembentuk sikap ada tiga yakni, kesadaran, perasaan dan perilaku.

Jenis penelitian yang digunakan pada penulisan ini adalah metode penelitian kuantitatif deskriptif. (Sugiyono, 2010), mengatakan penelitian kuantitatif dapat diartikan sebagai metode penelitian yang berlandaskan pada filsafat positivisme, digunakan untuk meneliti pada populasi atau sampel tertentu, pengumpulan data menggunakan instrument penelitian, analisis data bersifat kuantitatif/statistik, dengan tujuan menguji hipotesis yang telah ditetapkan.

Penelitian ini dilakukan dengan penelitian survey yang mana informasinya dikumpulkan dengan menggunakan kuesioner. Pada umumnya pengertian survey dibatasi pada penelitian yang datanya dikumpulkan dari sampel atas populasi untuk mewakili seluruh populasi. Penelitian survey adalah "penelitian-penelitian yang mengambil sampel dari suatu populasi dan mengunakan kuesioner sebagai alat pengumpul data yang pokok" (Sugiyono, 2010)

Populasi dalam penelitian ini adalah masyarakat di Desa Bojonggede, Kecamatan Bojonggede, Kabupaten Bogor berjumlah 47.235 jiwa. Penentuan lokasi dipilih dengan sengaja dengan pertimbangan bahwa Desa Bojonggede sebagai populasi penelitian karena mayarakat Bojonggede banyak yang ikut andil dalam gerakan boikot Ernest Prakasa di Twitter. Pelaksanaan penelitian berlangsung mulai dari awal bulan Juli 2017 hingga Akhir bulan Juli 2017.

\section{HASIL DAN PEMBAHASAN}

Ernest Prakasa lahir di Jakarta, Indonesia, 29 Januari 1982. Ernest Prakasa adalah seorang pelawak tunggal Indonesia. Ia dikenal sejak meraih peringkat ketiga dalam acara Stand Up Comedy Indonesia (SUCI) pada tahun 2011 dan juga dikenal sebagai seorang komedian Tionghoa-Indonesia yang sering menjadikan kehidupan etnisnya sebagai materi komedi tunggal.

Setelah menyelesaikan kuliah pada tahun 2005, Ernest kemudian bekerja di perusahaan rekaman sampai tahun 2011. Sebelumnya sejak tahun 2001, ia adalah seorang penyiar radio. Awal mulanya ia menjadi seorang komika adalah ketika mengikuti prgram Stand Up Comedy Indonesia di Kompas TV. Ernest berhasil menyabet juara 3 dalam acara tersebut dan kemudian memutuskan untuk menjadi seorang komika secara full time.

Ernest Prakasa juga tergabung dalam komunitas StandUpIndo. Ketika itu ia bersama Ryan (sesama peserta SUCI 1) untuk open mic di Comedy Cafe yang berada di daerah kemang. Singkat cerita, Ryan kemudian mengajak Pandji beserta Raditya Dika. Sementara Ernest mengajak Isman yang merupakan seorang penulis komedi. Al hasil Comedy Cafe yang hanya berkapasitas 50 orang itu disebur ratusan pengunjung. Video dalam event tersebut kemudian di uploud di youtube. Ternyata video itu mendapat respon yang sangat bagus sehingga pada event-event selanjutnya penontonya bisa sampai 1000 orang. Dan tanggal 13 Juli 2013 ditetapkan lahirnya StandUpIndo yakni komunitas stand up comedy di Indonesia dengan 5 co-founder (Ernest, Radit, Ryan, Panji dan Isman).

Kepopuleran Ernest semakin melambung ketika membintangi film bergenre action comedy yakni Comic 8. Selain itu ia juga menggelar Stand Up Comedy Tour di berbagai kota dengan tajuk "Illucinati".Di tahun 2014 Ernest Prakasa menorehkan rekor sebagai komedi tunggal pertama di Indonesia yang menggelar 3x pertunjukan dalam satu hari.

Awal karir Ernest adalah di industri musik, yakni dengan bergabung bersama Universal Music. Ia lalu melanjutkan kiprahnya di Sony Music. Nyaris enam tahun berkutat di industri musik, Ernest mendaftarkan diri ke program televisi Kompas TV, yakni Stand Up Comedy Indonesia. Ia berhasil lolos audisi dan terpilih menjadi satu dari 13 finalis dari seluruh Indonesia, dan meraih peringkat ketiga dalam kompetisi tersebut. Ernest akhirnya memutuskan diri untuk terjun dan menekuni profesi pelawak tunggal secara penuh. Bersama Raditya Dika, Pandji Pragiwaksono, Isman H. Suryaman dan Ryan Adriandhy, Ernest mendirikan Stand Up Indo, sebuah komunitas pelawak tunggal pertama di Indonesia, yang hingga kini telah memiliki subkomunitas di lebih dari 15 provinsi, dan dianggap sebagai salah satu perintis budaya komedi tunggal di Indonesia. Ernest pun diangkat sebagai Ketua pertama dari Stand Up Indo hingga Juni 2013.

Ernest telah melakukan sebuah tur komedi tunggal pada 2012, dan ia merupakan komedian pertama Indonesia yang melakukan hal itu. Tur tersebut dinamai Merem Melek, menjelajah 11 kota dari Bandung, Semarang, Solo, Denpasar, Malang, Surabaya, Makassar, Kendari, Samarinda, hingga Palangkaraya, dan ditutup di Gedung Kesenian Jakarta pada 10 Juli 2012. Ia juga pernah menggelar sebuah pertunjukan komedi tunggal khusus bersama para komedian dari etnis Tionghoa-Indonesia, berjudul Ernest Prakasa \& The Oriental Bandits yang digelar di Gedung Kesenian Jakarta pada 9 Februari 2013, sehari sebelum perayaan Imlek.

Berdasarkan hasil kuesioner yang dibagikan dengan cara mendatangi langsung responden dan memberikan beberapa pertanyaan singkat untuk mengetahui apakah responden sesuai dengan kriteria 
yang dibutuhkan peneliti, penelitian ini juga membagikan kuesioner secara online melalui google form kepada responden, kemudian didapatkan hasil sebagai berikut:

\section{a. Berdasarkan Followers Akun Twitter Ernest Prakasa}

\section{Tabel 6}

Data Distribusi Responden

Berdasarkan Followers Akun Twitter Ernest Prakasa

\begin{tabular}{|l|r|}
\hline $\begin{array}{l}\text { Follow } \\
\text { ers }\end{array}$ & $\begin{array}{c}\text { Frekue } \\
\text { nsi }\end{array}$ \\
\hline Ya & 71 \\
\hline Tidak & 29 \\
\hline Total & 100 \\
\hline
\end{tabular}

Berdasarkan tabel diatas diketahui sebanyak 71 orang $(71 \%)$ responden adalah followers dari akun twitter Ernest Prakasa, sedangkan 29 orang (29\%) responden belum menjadi followers akun twitter Ernest Prakasa.

b. Berdasarkan Jenis Kelamin

Tabel 7

Data Distribusi Responden Berdasarkan Jenis Kelamin

\begin{tabular}{|c|c|}
\hline $\begin{array}{c}\text { Jenis } \\
\text { Kelami } \\
\mathrm{n}\end{array}$ & $\begin{array}{c}\text { Frekue } \\
\text { nsi }\end{array}$ \\
\hline $\begin{array}{c}\text { Laki- } \\
\text { Laki }\end{array}$ & 57 \\
\hline $\begin{array}{c}\text { Peremp } \\
\text { uan }\end{array}$ & 43 \\
\hline Total & 100 \\
\hline
\end{tabular}

Berdasarkan tabel diatas diketahui ada 57 orang (57\%) responden berjenis kelamin laki-laki dan 43 orang $(43 \%)$ responden berjenis kelamin perempuan. c. Berdasarkan Umur

\section{Tabel 8}

Data Distribusi Responden Berdasarkan Umur

\begin{tabular}{|c|c|}
\hline Umur & $\begin{array}{c}\text { Frekuens } \\
\mathrm{i}\end{array}$ \\
\hline $\begin{array}{c}15-20 \\
\text { Tahu } \\
\mathrm{n}\end{array}$ & 6 \\
\hline $\begin{array}{c}21-26 \\
\text { Tahu } \\
\mathrm{n}\end{array}$ & 67 \\
\hline $\begin{array}{c}27-30 \\
\text { Tahu } \\
\mathrm{n}\end{array}$ & 14 \\
\hline $\begin{array}{c}30-35 \\
\text { Tahu } \\
\mathrm{n}\end{array}$ & 13 \\
\hline Total & 100 \\
\hline
\end{tabular}

Berdasarkan tabel diatas diketahui ada 6 Orang (6\%) responden berumur antara 15 - 20 tahun, ada 67 orang $(67 \%)$ responden berumur antara $21-26$ tahun, sebanyak 14 orang (14\%) responden berumur antara 27 - 30 tahun, dan sisanya sebanyak 13 Orang (13\%) responden berusia 30-35 tahun. Tabel 9

Data Distribusi Responden Berdasarkan Jenis Pekerjaan

\begin{tabular}{|l|c|}
\hline $\begin{array}{c}\text { Pekerja } \\
\text { an }\end{array}$ & $\begin{array}{c}\text { Frekue } \\
\text { nsi }\end{array}$ \\
\hline Sekolah & 15 \\
\hline Kuliah & 42 \\
\hline $\begin{array}{l}\text { Wiraswa } \\
\text { sta }\end{array}$ & 37 \\
\hline $\begin{array}{l}\text { Wirausa } \\
\text { ha }\end{array}$ & 6 \\
\hline Total & 100 \\
\hline
\end{tabular}

Berdasarkan tabel diatas diketahui ada 15 Orang (15\%) responden berumur yang masih sekolah, ada 42 orang $(42 \%)$ responden yang masih kuliah, sebanyak 37 orang $(37 \%)$ responden wiraswasta dan sisanya sebanyak 6 Orang $(6 \%)$ responden wirausaha.

Validitas menunjukkan sejauh mana alat pengukur yang dipergunakan untuk mengukur apa yang diukur. Sebelum melakukan pengujian hubungan ataupun pengaruh, butir pertanyaan harus diuji kebenarannya. Adapun caranya adalah dengan mengkorelasikan antara skor yang diperoleh pada masing-masing item pertanyaan dengan skor total individu.

Pengujian validitas dilakukan dengan menggunakan banntuan IBM SPSS 21.0 for windows dan rumus manual. Dalam penelitian ini pengujian validitas hanya dilakukan terhadap 100 responden. Pengambilan keputusan berdasarkan pada nilai $\mathrm{r}$ hitung (Corrected Item-Total Correlation) $>r_{\text {tabel }}$ sebesar 0,1564 (lampiran), untuk df $=100-2=98$ dengan $\alpha=0,10$ maka item atau pertanyaan tersebut valid dan begitu sebaliknya.

Setelah hasil analisis data penelitian, selanjutnya adalah mendeskripsikan hasil penelitian tersebut dalam bentuk tabel yang menggambarkan pengaruh tulisan Ernest Prakasa mengenai DR Zakir Naik di twitter terhadap citra Ernest Prakasa di Desa Bojonggede

Tabel 19

Tabel Rekapitulasi Hasil Penelitian

\begin{tabular}{|c|c|c|c|c|}
\hline $\begin{array}{c}\text { Hipote } \\
\text { sis } \\
\begin{array}{c}\text { Penelit } \\
\text { ian }\end{array}\end{array}$ & $\begin{array}{c}\text { Hasil } \\
\text { peneliti } \\
\text { an }\end{array}$ & $\begin{array}{c}\text { Kriter } \\
\text { ia } \\
\text { peneli } \\
\text { tian }\end{array}$ & $\begin{array}{c}\text { Interpr } \\
\text { etasi }\end{array}$ & $\begin{array}{c}\text { Kesimp } \\
\text { ulan }\end{array}$ \\
\hline
\end{tabular}




\begin{tabular}{|c|c|c|c|c|}
\hline $\begin{array}{l}\text { Terdap } \\
\text { at } \\
\text { pengar } \\
\text { uh } \\
\text { tulisan } \\
\text { Ernest } \\
\text { Prakasa } \\
\text { menge } \\
\text { nai DR } \\
\text { Zakir } \\
\text { Naik di } \\
\text { twitter } \\
\text { terhada } \\
\text { p citra } \\
\text { Ernest } \\
\text { Prakasa } \\
\text { di Desa } \\
\text { Bojong } \\
\text { gede }\end{array}$ & $\begin{array}{l}t_{\text {hitung }} \\
(15,764) \\
\text { dengan } \\
\text { perhitun } \\
\text { gan } \\
\text { menggu } \\
\text { nakan } \\
\text { IBM } \\
\text { SPSS } \\
21.0 \text { for } \\
\text { windows }\end{array}$ & $\begin{array}{l}t_{\text {tabel }} \\
= \\
1,660 \\
\text { (taraf } \\
10 \%) \\
\text { berarti } \\
\text { signifi } \\
\text { kan } \\
t_{\text {hitung }} \\
> \\
t_{\text {tabel }}\end{array}$ & $\begin{array}{l}\text { Hipotes } \\
\text { is } \\
\text { diterim } \\
\text { a }\end{array}$ & $\begin{array}{l}\text { Terdapa } \\
\mathrm{t} \\
\text { pengaru } \\
\text { h yang } \\
\text { signifik } \\
\text { an } \\
\text { tulisan } \\
\text { Ernest } \\
\text { Prakasa } \\
\text { mengen } \\
\text { ai DR } \\
\text { Zakir } \\
\text { Naik di } \\
\text { twitter } \\
\text { terhada } \\
\text { p citra } \\
\text { Ernest } \\
\text { Prakasa } \\
\text { di Desa } \\
\text { Bojong } \\
\text { gede }\end{array}$ \\
\hline
\end{tabular}

Penelitian ini dilaksanakan dengan tujuan untuk mengetahui pengaruh serta besar pengaruh tulisan Ernest Prakasa mengenai DR Zakir Naik di twitter terhadap citra Ernest Prakasa di Desa Bojonggede. Dalam penelitian ini beberapa sampel yang diambil sebanyak 100 responden terpilih.

Berdasarkan penyajian data dan analisis data terkait penelitian sekarang, hasilnya menunjukan bahwa kuesioner telah valid dan reliabilitas dengan tingkat reliabilitas variabel $\mathrm{X}$ sebesar 0,938 sedangkan variabel Y sebesar 0,916. Data tersebut jika di sinkronisasikan dengan tabel tingkat reliabilitas terdapat korelasi yang sangat kuat, artinya jika kuesioner telah reliable maka kuesioner juga telah valid setiap butir pernyataannya.

Setelah melakukan uji instrument penelitian, peneliti menyebarkan kuesioner sesuai dengan target penelitian dan menganalisa. Peneliti melakukan analisis data dengan uji hipotesis yaitu ingin mengetahui berpengaruh atau tidaknya dan seberapa besar pengaruh tersebut. Berdasarkan penyajian data dan analisis data terkait penelitian sekarang, hasilnya menunjukan bahwa terdapat pengaruh yang signifikan antara $t_{\text {hitung }}$ dengan $t_{\text {tabel }}$. Yang diperoleh dari $t_{\text {hitung sesuai }}$ perhitungan yaitu 15,764 sedangkan $t_{\text {tabel }}$ pada taraf signifikan $10 \%$ adalah 1,6602 .

Sehingga dapat disimpulkan bahwa terdapat pengaruh yang signifikan tulisan Ernest Prakasa mengenai DR Zakir Naik di twitter terhadap citra Ernest Prakasa di Desa Bojonggede. Sesuai dengan persamaan regresi yaitu $\hat{Y}=9,156+0,785(\mathrm{X})$. dapat diartikan jika variabel $\mathrm{X}$ yaitu tulisan Ernest Prakasa mengenai DR Zakir Naik di twitter lebih sering atau meningkat, maka citra negatif Ernest Prakasa di Desa Bojonggede juga akan meningkat. Begitu juga sebaliknya jika tulisan Ernest Prakasa mengenai DR Zakir Naik di twitter menurun maka citra negatif Ernest Prakasa di Desa Bojonggede juga akan menurun.

Analisa Penelitian dengan model komunikasi SMCR (Mulyana, 2007)

1. Source (Sumber)

Ernest Prakasa sebagai sumber atau penyampai pesan. Sebagai publik figur, Ernest Prakasa dituntut untuk mempunyai sikap dan perilaku yang baik. Ernest Prakasa juga harus mempunyai kemampuan menulis yang baik dan bermanfaat untuk masyarakat, karena publik figur itu sangat dekat sekali kaitannya dengan masyarakat. Publik figur harus menjadi contoh yang baik untuk masyarakat. Dalam penelitian ini, Ernest Prakasa dianggap telah melakukan kesalahan dalam menyampaikan pesan mengenai DR Zakir Naik di twitter, tetapi Ernest Praksaa sudah melakukan hal baik dengan langsung meminta maaf dan menghapus tulisannya di twitter mengenai DR Zakir Naik.

2. Message (pesan)

Pesan yang disampaikan Ernest Prakasa harus disertai dengan ilmu pengetahuan dan sumber yang jelas serta bisa membuktikannya. Pada penelitian ini Ernest Prakasa sudah memberikan bukti kepada pengguna twitter dengan memberikan hasil screenshot tulisan dari media Inggris, yaitu Daily Mail. Tetapi setelah peneliti melakukan penelusuran dari beberapa sumber di internet, ternyata ditemukan bahwa Daily Mail adalah media Inggris yang subjektif, sehingga keakuratan beritanyapun diragukan oleh masyarakat.

3. Channel (Saluran)

Saluran yang digunakan Ernest Prakasa dalam menyampaikan pesan adalah media sosial twitter. Media sosial twitter adalah salah satu media sosial yang cepat dan mudah digunakan oleh sebagian besar penduduk di Indonesia. Jadi, ketika Ernest Prakasa menulis tentang DR Zakir Naik di twitter, otomatis tulisan tersebut dengan cepat muncul di timeline twitter dan bisa dibaca oleh sebagian besar penduduk di Indonesia, khususnya di Desa Bojonggede..

4. Receiver (Penerima Pesan)

Penerima pesan dalam penelitian ini adalah masyarakat pengguna twitter di desa Bojonggede Kabupaten Bogor. Peneliti melihat bahwa pengguna twitter di Bojonggede tidak senang dengan keberadaan tulisan Ernest Prakasa mengenai DR Zakir Naik di twitter. 
Pengguna twitter di Desa Bojonggede mengkritik bahkan membalas tulisan Ernest Prakasa tersebut dengan hujatan dan makian. Kemudian pengguna twitter di Desa Bojonggede juga ikut meramaikan tanda pagar \#BoikotErnestPrakasa.

Proses pembentukkan citra Ernest Prakasa melalui tulisan di twitter diawali dari pengguna twitter yang membaca dan memperhatikan maksud dan tujuan dari tulisan Ernest Prakasa mengenai DR Zakir Naik. Perhatian pengguna twitter tersebut memberikan pengalaman indrawi penglihatan, pengalaman perasaan, pengalaman berpikir, pengalaman bertindak, dan pengalaman berhubungan. Pengalaman-pengalaman yang didapat oleh pengguna twitter yang membaca tulisan tersebut membentuk kesan dan keyakinan tentang tulisan Ernest Prakasa mengenai DR Zakir Naik. Perubahan citra Ernest Prakasa terbentuk karena Ernest Prakasa sebagai penyampai pesan tidak sesuai memberikan informasi yang disampaikan dengan apa yang diharapkan oleh pengguna twitter.

\section{Kesimpulan}

Penelitian ini mengungkapkan data kuantitatif mengenai pengaruh tulisan Ernest Prakasa mengenai DR Zakir Naik di twitter terhadap citra negatif Ernest Prakasa di Desa Bojonggede. Adapun teknik analisis data yang digunakan oleh penulis yaitu dengan menggunakan statistik parametrik uji regresi dan korelasi. Berdasarkan hasil analisa pembahasan dalam penulisan skripsi ini, maka peneliti dapat menarik kesimpulan sebagai berikut :

1. Hasil dari pengolahan yang terkumpul menunjukan tulisan Ernest Prakasa mengenai DR Zakir Naik di twitter memiliki pengaruh yang positif dan signifikan dengan citra negatif Ernest Prakasa di Desa Bojonggede.

2. Hasil pengolahan data melalui uji regresi sebagai uji pengaruh dan uji korelasi untuk mengetahui seberapa besar pengaruh pada fenomena tersebut. Uji tersebut menunjukan bahwa terdapat $71,7 \%$ menyatakan bahwa citra negatif Ernest Prakasa di Desa Bojonggede terpengaruh akibat dari tulisan Ernest Prakasa mengenai DR Zakir Naik di twitter, sebaliknya terdapat $28,3 \%$ terpengaruh akibat dari faktor luar.

3. Jika hasil berpengaruh, peneliti mendapatkan persamaan regresi antara tulisan Ernest Prakasa mengenai DR Zakir Naik di twitter dengan citra negatif Ernest Prakasa di Desa Bojonggede. Persamaan regresi adalah hubungan fungsional antara variabel-variabel yang didapatkan dari alat ukur yaitu regresi (pengaruh).

Persamaan regresi tersebut dapat diartikan jika tulisan Ernest Prakasa mengenai DR Zakir
Naik di twitter bertambah dari penelitian sekarang maka citra negatif Ernest Prakasa di Desa Bojonggede akan bertambah juga.

\section{REFERENSI}

Ardianto Elvinaro dan Soemirat. (2007). DasarDasar Public Relations. Bandung: Simbiosa Rekatama.

Bimo Walgito. (2010). Pengantar Psikologi Umum. Yogyakarta: Andi Offset.

Dixon, B. (2012). Social Media for School Leaders. Usa: Jossey-Bass.

Junaedi, F. (2013). Media Parenting. Bogor: Buku Literia.

Lesmana, A. (2012). Analisis Pengaruh Media Sosial Twitter Terhadap Pembentukan Brand Attachment. universitas indonesia.

McQuail, D. (2011). Teori Komunikasi Massa. Jakarta: Salemba Humanika.

Mulyana, D. (2007). Penghantar Ilmu Komunikasi. Bandung: Rosda.

Puntoadi, D. (2011). Menciptakan Penjualan Melalui Social Media. Jakarta: PT Elex Komputindo.

Purnama, H. (2011). Media Sosial di Era Pemasaran 3.0. Corporate and Marketing Communication. Komunikasi, 107-124., 107-124.

Rakhmat, J. (2009). Metode Penelitian Komunikasi. Remaja Rosdakarya.

Sugiyono. (2010). Metode Penelitian Kuantitatif Kualitatif dan $R \& D$ perbesar gambar. Bandung: Alfabeta.

Bimo Walgito. 2002. Pengantar Psikologi Umum. Yogyakarta: Andi Offset

Dixon, Bryan. 2012. Social Media For School Leaders. USA: Josey Bass.

Djibran, Fahd. 2008. Writing is Amazing. Yogyakarta: Juxtapose

Effendy, Onong Uchjana. 2007. Ilmu Komunikasi Teori dan Praktek. Bandung: PT Remaja Rosdakarya.

\section{PROFILE PENULIS}

Rio Septian aktif sebagai Akademisi di Bina Sarana Informatika sebagai dosen teori di Universitas Bina Sarana Informatika Jakarta. Kritik dan saran sangat diharapkan guna peningkatan kualitas dan penulisan selanjutnya. 